\title{
Molecular and microscopic detection of Babesia caballi and Theileria equi among working horses and donkeys in Cairo and Giza provinces of Egypt
}

\author{
Ahmed M. Soliman ( $D$ ahmed.mahmoud8933@yahoo.com) \\ Biotechnology Department, Animal Health Research Institute, Agricultural Research Center, Dokki12618, Giza, Egypt \\ https://orcid.org/0000-0002-3657-4781
}

\section{Nagwa M. Elhawary}

Parasitology Department, Faculty of Veterinary Medicine, Kafr El-Sheikh University, 33516 Kafrelsheikh, Egypt

Nashwa M. Helmy

Biotechnology Department, Animal Health Research Institute, Agricultural Research Center, Dokki12618, Giza, Egypt

Sahar M. Gadelhaq

Parasitology Department, Faculty of Veterinary Medicine, Minia University, Al-Minia, Egypt

\section{Research Article}

Keywords: Equine piroplasmosis, Theileria equi, Babesia caballi, PCR, Egypt

Posted Date: August 2nd, 2021

DOI: https://doi.org/10.21203/rs.3.rs-757240/v1

License: (c) (i) This work is licensed under a Creative Commons Attribution 4.0 International License. Read Full License 


\section{Abstract}

Equine piroplasmosis (EP) is an ixodid tick-borne disease caused by Theileria equi and/or Babesia caballi that can lead to severe health issues and economic losses among equine population. This study aimed to determine the prevalence of $T$. equi and B. caballi among Egyptian equines based on microscopy and conventional PCR. Also, to determine the effect of season, age, and sex of on their prevalence and determining the difference in sensitivity between microscopy and conventional PCR in the diagnosis of EP. This study was carried out on 432 blood samples randomly collected from 146 horses and 286 donkeys during a period from April 2016 to March 2018. Microscopic examination revealed that among horses, $13(8.9 \%)$ and $4(2.7 \%)$ were infected by $T$. equi and $B$. caballi respectively. While among donkeys, 22 (7.7\%), 16 (5.6\%) respectively. While mixed infections were detected in 4 (1.4\%) donkeys. There was a statistically nonsignificant relation between prevalence of infection and season and sex of equines but the highest prevalence was recorded in age group less than 5 years old. By conventional PCR, among 64 horses, 15 (23.4\%) and 8 (12.5\%) were infected by T. equi and B. caballi, respectively. While among 76 donkeys, 36 (47.4\%), 16 (21.1\%), and 5 (6.6\%) were infected by T. equi, B. caballi, and mixed infection, respectively. Our finding proved the existence of T. equi and $B$. caballi among equines.

\section{Introduction}

Members of family Equidae either wild or domestic ones are affected by a haemoprotozoic disease of widespread geographical distribution and international economic importance called Equine piroplasmosis (EP) that may progress as hyperacute, acute, subacute, or chronic illness (Mehlhorn and Schein, 1998). Ixodid ticks including the genera Dermacentor, Hyalomma, and Rhipicephalus are the main transmitters of the causative organisms (Babesia caballi (B. caballi) and Theileria equi (T. equi)) which are Intra-erythrocytic piroplasms belonging to phylum Apicomplexa that are endemic in tropical, subtropical, and temperate areas of the world (Rothschild, 2013). In addition to ectoparasitic way of transmission, piroplasms can also can be transmitted iatrogenically by blood transfusion or by using contaminated needles or surgical instruments (Homer et al., 2000; Zobba et al, 2008; Farkas et al., 2013).

B. caballi and T. equi can cause variable and nonspecific symptoms such as transient fever, jaundice, petechial hemorrhages, bilirubinuria, hemoglobinuria, distal limb edema, poor

performance, loss of body conditions, inappetence, abortions, and even death (Zweygarth et al.,

2002; Malekifard et al., 2014). Infected equines may remain carriers for $B$. caballifor several years while in case of $T$. equi, infected equines can remain carriers for their whole life. These carrier animals represent a huge threat as a source of infective stages of piroplasms for tick vectors (Rüegg et al., 2007). Mixed infections were documented in different countries where a common vector is present (Scoles and Ueti, 2015). Some factors have a great effect on the spreading of EP such as climatic conditions and transnational movement of equids. So, proper control policies must be directed toward importing equines. Serological examinations are commonly applied between borders for controlling equine movement (Sigg et al., 2010; Guidi et al., 2015).

Diagnosis of EP depends mainly on direct (microscopical examination and molecular techniques) and indirect (serological examinations) methods. The gold standard for diagnosis of EP is a microscopical examination of stained blood smears but it is highly significant only during

the acute infection while it is of low sensitivity in the case of carrier animals due to low parasitemia (Quintão-Silva and Ribeiro, 2003). Several serological examinations were applied for the detection of antibodies against $B$. caballi 
and T. equi such as complement fixation test (CFT), immunofluorescent antibody technique (IFAT), and enzymelinked immunosorbent assay

(ELISA) (Kim et al., 2008). These serological tests are more sensitive but have some drawbacks

related to cross-reactivity to other Babesia species and antibody detection limit. Molecular

techniques were proved to have the highest sensitivity among the diagnostic procedures (BrÜning et al., 1997). With parasitemia as low as $0.000001 \%$, the polymerase chain reaction (PCR) can detect parasitic DNA from a blood sample (Alhassan et al., 2005; El-Seify et al., 2018).

In Egypt, Studies on B. caballi and T. equi are infrequent and slight data had been provided. Therefore, this study aimed to determine the infection rate of $T$. equi and $B$. caballi among equines in Cairo and Giza governorates, Egypt based on microscopic examinations of Giemsa-stained blood films and Polymerase Chain Reaction (PCR). Also, this study aimed to determine the effect of season, age, and sex of on the infection rate and determining the difference in sensitivity between microscopic examination and molecular techniques in the diagnosis of EP.

\section{Materials And Methods}

\section{Sampling and study design}

This study was conducted on 432 blood samples from apparently healthy equids including 146 horses and 286 donkeys, which were randomly selected from different localities belonging to Cairo and Giza governorates, Egypt during a period from April 2016 to March 2018. The samples were collected by jugular venipuncture method using EDTA-tubes. All samples were labeled by necessary data (age, sex, and date of collection) then were transported in an icebox to the Parasitology Department, Faculty of Veterinary Medicine, Kafrelshiekh University for examination.

\section{Microscopic examination}

In the lab, thin and thick whole blood films were done, stained by Giemsa stain according to (Levine, 1982), and examined for the presence of intra-erythrocytic merozoites of $B$. caballi and T. equi using oil emersion lens of the light microscope. The remaining blood was kept at $-80^{\circ} \mathrm{C}$ until further molecular examinations.

\section{DNA extraction}

Genomic DNA was extracted from blood samples showed positive results of EP in addition to some randomly selected microscopically negative samples using Thermo Scientific ${ }^{\text {TM }}$ GeneJET Genomic DNA Purification Kit (Cat No \#K0722) according to manufacturer's instructions. The obtained DNA was stored at $-20^{\circ} \mathrm{C}$ until used in the downstream applications. Molecular analysis was done in Biotechnology Department, Animal Health Research Institute, Giza, Egypt.

\section{PCR amplification}

Conventional PCR technique was performed via primers established by (Alhassan et al.,

2005). that specifically amplify fragments of $540 \mathrm{bp}$ and $392 \mathrm{bp}$ from $18 \mathrm{~s}$ rRNA gene of $B$. caballi and T. equi, respectively. We applied a universal forward primer (Bec-UF2) with a sequence 5-TCGAAGACGATCAGATACCGTCG-3, a $B$. caballi specific reverse primer (Cab-R) with a sequence 5'-CTCGTT CATGATTTAGAATTGCT-3' and a T. equi specific reverse primer (Equi-R) with a sequence 5-TGCCTTAAACTTCCTTGCGAT-3. 
PCR was performed using GoTaq ${ }^{\circledR}$ G2 Flexi PCR Kit (Promega, USA) with a total volume of $25 \mu$ containing $5 X$ Green GoTaq® Flexi Buffer $(10 \mu \mathrm{l}), 25 \mathrm{mM} \mathrm{MgCl} 2$ Solution $(2 \mu \mathrm{l})$, PCR Nucleotide Mix (dNTPs) $10 \mathrm{mM}$ each $(1 \mu \mathrm{l})$, Primer mix 10 pmol $(1 \mu \mathrm{l}), 1.25 \mathrm{u}$ GoTaq ${ }^{\circledR G} 2$ Flexi DNA Polymerase template DNA (5 $\left.\mu \mathrm{l}\right)$, DNase/RNase free water (6 $\left.\mu \mathrm{l}\right)$ (two PCR tubes one for $B$. caballi and the other for $T$. equi). The thermal profile was $95^{\circ} \mathrm{C}$ for 5 min, followed by 35 cycles of repeated denaturation at $96^{\circ} \mathrm{C}$ for $1 \mathrm{~min}$, annealing at $60^{\circ} \mathrm{C}$ for $1 \mathrm{~min}$, and extension at $72^{\circ} \mathrm{C}$ for $1 \mathrm{~min}$. then a final extension at $72^{\circ} \mathrm{C}$ for $5 \mathrm{~min}$, after that holding stage at $4^{\circ} \mathrm{C}$ for an infinite time. $8 \mu$ of the generated PCR products were migrated on $1.5 \%$ ethidium bromide-stained agarose gel under a constant voltage of $80 \mathrm{~V}$ for $40 \mathrm{~min}$. visualization of agarose gel by Gel documentation system (XR) (Bio-Rad.UK). B. caballi and T. equi positive samples showed a band of 540 pb 392 bp, respectively.

\section{Statistical analysis}

The statistical analysis was done by using the statistical package Microsoft Excel software. Data were computed and represented in figures. The relationship between equine infection rate and risk factors such as age and sex were determined by Chi-square analysis with Fisher's exact option (SPSS, Version 17.0, Chicago, IL). Statistical significance was declared at $P<0.05$.

\section{Results}

\section{Microscopical findings:}

Results of microscopic examination revealed that B. caballi was found in horses at a rate of $4 / 146(2.7 \%)$ and in donkeys at a rate of $16 / 286(5.6 \%)$, while $T$. equi was prevalent in horses at a rate of $13 / 146(8.9 \%)$ and donkeys at a rate of 22/286 (7.7\%). Mixed infection was observed only in donkeys at a rate of $4 / 286(1.4 \%)$. (Table 1 ). Microscopically, B. caballi appeared as large Babesia measuring 2.5-4 $\mu \mathrm{m}$ in length double pyriform or single pyriform while T. equi appeared as small Babesia measuring $2 \mu \mathrm{m}$ in length single round, double round, single pyriform, and maltase cross shapes.

(Table 2) showed the effect of Season, Age, and Sex on the prevalence of $B$. caballi among horses and donkeys by microscopic examination of Giemsa-stained blood smears as follows: seasonal prevalence of $B$. caballi among horses was the highest in winter (4.5\%). While amongst donkeys the highest was in summer (10.2\%). The highest prevalence of $B$. caballi in horses was in $>15$ years old animals (15.8\%) While in donkeys, the highest prevalence of B. caballi was in young donkeys under 5 years (13.2\%). The prevalence of $B$. caballi in female horses was (2.9\%) which is slightly higher than in males (2.6\%) while in donkeys, the prevalence in males was (6.2\%) higher than in females (4.8\%).

(Table 3) illustrated the effect of Season, Age, and Sex on the prevalence of T. equi among horses and donkeys by microscopic examination of Giemsa-stained blood smears as follows: seasonal prevalence of $T$. equi among horses was the highest in autumn (11.5\%). While amongst donkeys the highest was in winter (15.4\%). The highest prevalence of $T$. equi in horses was in the age group beneath 5 years old animals $(16.7 \%)$. While in donkeys, the highest prevalence of $T$. equi was in young donkeys under 5 years (11.8\%). The prevalence of $T$. equi in male horses was $(11.8 \%)$ which is higher than females (5.7\%) while in donkeys, the prevalence in males was $(9.3 \%)$ higher than females (5.6\%).

Chi-Square test was applied to detect the relation between prevalence of EP and equine species, season, sex, and age of equines. The obtained Chi2 values in the case of equine species, season, and sex showed insignificant at $p$. value $(a \leq 0.05)$ which means that prevalence of infection and species, season, and sex of collected samples are 
independent factors. While for animals age, the obtained Chi2 value showed the highest prevalence of infection was among age group $<5$ years compared with other age groups so, it was significant at $p$. value $(a \leq 0.05)$ which means that prevalence of infection and age of equines are two correlated factors.

Table 1

Prevalence of T. equi and B. caballi among horses and donkeys by microscopic examination of Giemsa-stained blood smears.

\begin{tabular}{|lllllllll|}
\hline Species & Total Number & T. equi & & B. caballi & \multicolumn{3}{c|}{ Mixed Infection } \\
\cline { 3 - 8 } & & No. of infected & $\%$ & No. of infected & $\%$ & No. of infected & $\%$ \\
\hline Horse & 146 & 13 & 8.9 & 4 & 2.7 & 0 & 0.0 \\
\hline Donkey & 286 & 22 & 7.7 & 16 & 5.6 & 4 & 1.4 \\
\hline Total & 432 & 35 & 8.1 & 20 & 4.6 & 4 & 0.9 \\
\hline
\end{tabular}

Table 2

Effect of Season, Age, and Sex on the prevalence of $B$. caballi among horses and donkeys by microscopic examination of Giemsa-stained blood smears.

\begin{tabular}{|c|c|c|c|c|c|c|c|c|c|c|c|c|c|}
\hline \multirow[t]{2}{*}{ Species } & \multirow[t]{2}{*}{ No. } & \multirow[t]{2}{*}{ Season } & \multirow[t]{2}{*}{ No. } & \multicolumn{2}{|c|}{ Infected } & \multirow{2}{*}{$\begin{array}{l}\text { Age } \\
\text { Group }\end{array}$} & \multirow[t]{2}{*}{ No. } & \multicolumn{2}{|c|}{ Infected } & \multirow[t]{2}{*}{ Sex } & \multirow[t]{2}{*}{ No. } & \multicolumn{2}{|c|}{ Infected } \\
\hline & & & & No. & $\%$ & & & No. & $\%$ & & & No. & $\%$ \\
\hline \multirow[t]{4}{*}{ Horse } & \multirow[t]{4}{*}{146} & Spring & 48 & 1 & 2.1 & $<5 \mathrm{Y}$ & 24 & 0 & 0.0 & \multirow[t]{2}{*}{ Male } & \multirow[t]{2}{*}{76} & \multirow[t]{2}{*}{2} & \multirow[t]{2}{*}{2.6} \\
\hline & & Summer & 28 & 0 & 0.0 & $5 / 10 \mathrm{Y}$ & 52 & 1 & 1.9 & & & & \\
\hline & & Autumn & 26 & 1 & 3.8 & $10 / 15 Y$ & 51 & 2 & 3.9 & \multirow[t]{2}{*}{ Female } & \multirow[t]{2}{*}{70} & \multirow[t]{2}{*}{2} & \multirow[t]{2}{*}{2.9} \\
\hline & & Winter & 44 & 2 & 4.5 & $>15 Y$ & 19 & 1 & 15.8 & & & & \\
\hline \multirow[t]{4}{*}{ Donkey } & \multirow[t]{4}{*}{286} & Spring & 65 & 4 & 6.2 & $<5 Y$ & 76 & 10 & 13.2 & \multirow[t]{2}{*}{ Male } & \multirow[t]{2}{*}{162} & \multirow[t]{2}{*}{10} & \multirow[t]{2}{*}{6.2} \\
\hline & & Summer & 59 & 6 & 10.2 & $5 / 10 \mathrm{Y}$ & 77 & 4 & 5.0 & & & & \\
\hline & & Autumn & 91 & 4 & 4.4 & $10 / 15 Y$ & 45 & 1 & 2.2 & \multirow[t]{2}{*}{ Female } & \multirow[t]{2}{*}{142} & \multirow[t]{2}{*}{6} & \multirow[t]{2}{*}{4.8} \\
\hline & & Winter & 71 & 2 & 2.8 & $>15 \mathrm{Y}$ & 88 & 1 & 1.1 & & & & \\
\hline
\end{tabular}


Table 3

Effect of Season, Age, and Sex on the prevalence of T. equi among horses and donkeys by microscopic examination of Giemsa-stained blood smears.

\begin{tabular}{|c|c|c|c|c|c|c|c|c|c|c|c|c|c|}
\hline \multirow[t]{2}{*}{ Species } & \multirow[t]{2}{*}{ No. } & \multirow[t]{2}{*}{ Season } & \multirow[t]{2}{*}{ No. } & \multicolumn{2}{|c|}{ Infected } & \multirow{2}{*}{$\begin{array}{l}\text { Age } \\
\text { Group }\end{array}$} & \multirow[t]{2}{*}{ No. } & \multicolumn{2}{|c|}{ Infected } & \multirow[t]{2}{*}{ Sex } & \multirow[t]{2}{*}{ No. } & \multicolumn{2}{|c|}{ Infected } \\
\hline & & & & No. & $\%$ & & & No. & $\%$ & & & No. & $\%$ \\
\hline \multirow[t]{4}{*}{ Horse } & \multirow[t]{4}{*}{146} & Spring & 48 & 5 & 10.4 & $<5 Y$ & 24 & 4 & 16.7 & \multirow[t]{2}{*}{ Male } & \multirow[t]{2}{*}{76} & \multirow[t]{2}{*}{9} & \multirow[t]{2}{*}{11.8} \\
\hline & & Summer & 28 & 3 & 10.7 & 5/10 Y & 52 & 4 & 7.7 & & & & \\
\hline & & Autumn & 26 & 3 & 11.5 & $10 / 15 Y$ & 51 & 2 & 3.9 & \multirow[t]{2}{*}{ Female } & \multirow[t]{2}{*}{70} & \multirow[t]{2}{*}{4} & \multirow[t]{2}{*}{5.7} \\
\hline & & Winter & 44 & 2 & 4.5 & $>15 Y$ & 19 & 3 & 15.8 & & & & \\
\hline \multirow[t]{4}{*}{ Donkey } & \multirow[t]{4}{*}{286} & Spring & 65 & 4 & 6.2 & $<5 Y$ & 76 & 9 & 11.8 & \multirow[t]{2}{*}{ Male } & \multirow[t]{2}{*}{162} & \multirow[t]{2}{*}{15} & \multirow[t]{2}{*}{9.3} \\
\hline & & Summer & 59 & 1 & 1.7 & 5/10 Y & 77 & 4 & 5.0 & & & & \\
\hline & & Autumn & 91 & 14 & 15.4 & 10/15Y & 45 & 4 & 8.9 & \multirow[t]{2}{*}{ Female } & \multirow[t]{2}{*}{142} & \multirow[t]{2}{*}{7} & \multirow[t]{2}{*}{5.6} \\
\hline & & Winter & 71 & 3 & 4.2 & $>15 \mathrm{Y}$ & 88 & 5 & 5.7 & & & & \\
\hline
\end{tabular}

\section{Molecular findings:}

By application of conventional PCR on 140 blood samples, the prevalence of equine piroplasms in horses and donkeys was $24 / 140(17.1 \%)$ and $52 / 140$ (37.1\%), respectively.

The molecular prevalence of $T$. equi, in horses and donkeys were 15/64 (23.4\%) and 36/64 (47.4\%), respectively, in case of B. caballi was 8/76 (12.5\%) and 16/67 (21.1\%), among horses and donkeys, respectively. Mixed infection observed only in donkeys by the rate of $5 / 76$ (6.6\%) (Table 4). The PCR product of B. caballi and T. equi were 540 bp and 392 bp, respectively (Fig. 1) and (Fig. 2), respectively.

Comparison between microscopical examination and conventional PCR for diagnosis of EP was statistically significant at $p$. value $(a \leq 0.001)$. So, our results showed that PCR is a more sensitive and accurate diagnostic method than microscopic examination of blood smears for the detection of equine piroplasms.

Table 4

Molecular prevalence of $B$. caballi and T. equi infection among horses, donkeys, and mules by conventional PCR

\begin{tabular}{|lccccccc|}
\hline Species & \multirow{2}{*}{ No. } & \multicolumn{2}{l}{ B. caballi } & \multicolumn{2}{l}{ T. equi } & \multicolumn{2}{l|}{ Mixed infection } \\
\cline { 3 - 8 } & & No. & $\%$ & No. & $\%$ & No. & $\%$ \\
\hline Horse & 64 & 8 & 12.5 & 15 & 23.4 & 0 & 0.0 \\
\hline Donkey & 76 & 16 & 21.1 & 36 & 47.4 & 5 & 6.6 \\
\hline Total & 140 & 24 & 17.1 & 51 & 36.4 & 5 & 3.6 \\
\hline
\end{tabular}

Fig 1. Detection of $B$. caballi by Conventional

PCR at 540 bp fractionated on $1.5 \%$ agarose gel.

Lane M: 50 bp DNA ladder, Lane 1: B. caballi 
negative control, Lane 2: B. caballi positive control, Lane 3-14 B. caballi positive field samples.

PCR at 392 bp fractionated on 1.5\% agarose gel. Lane M: 50 bp DNA ladder, Lane 1: T. equi negative control, Lane 2: T. equi positive control, Lane 3-14 T. equi positive field samples

\section{Discussion}

The objectives of this study were to determine the infection rate of $B$. caballi and $T$. equi among the equine population in Cairo and Giza provinces of Egypt based on microscopic examinations and molecular techniques (PCR) in addition to studying the effect of season, age, and sex of infected animals on the infection rate and differentiation between microscopic examination and molecular techniques in the diagnosis of EP. For many years, the standard diagnostic and highly specific method for EP was the microscopical examination of stained blood smears. But, due to low parasitemia in carrier animals, it is significant only during the acute phase of infection. So, we applied a conventional PCR technique that proved to be more sensitive than microscopical examination in such cases.

Equine piroplasms can be recognized based on biometrical and morphometric data. In the current study, $B$. caballi appeared as large Babesia measuring 2.5 to $4 \mu \mathrm{m}(>2.5 \mu \mathrm{m})$, double pyriform, or single pyriform. while $T$. equi appeared as small Babesia measuring $2 \mu \mathrm{m}$ in length $(<2.5 \mu \mathrm{m})$, single round, double round, single pyriform, and maltase cross shapes. The morphological characteristics observed in $B$. caballi and $T$. equi in the current study were in agreement with the findings of (Selim and Abd El-Gawad, 1982; Levine, 1982).

In the current study, microscopic examination of blood smears showed an overall prevalence of T. equi was (8.1\%) which was in agreement with (Inci, 2002) in Turkey (8.7\%). While higher than (El-Fayoumy and Iman, 2006) in Egypt (7.2\%) and (Malekifard et al., 2014) in Iran (6.25\%). And lower than that recorded in Egypt by (18\%) by (Ibrahim et al., 2011), (9.4\%) by (El-Kelesh et al., 2012), in Ethiopia (12.2\%) by (Gizachew et al., 2013), and in India (14.14\%) by (Sumbria et al., 2016). While the overall prevalence of $B$. caballi was (4.6\%) which was in agreement with (El-Fayoumy and Iman, 2006) in Egypt (4.8\%). but higher than (Gizachew et al., 2013) in Ethiopia (1.8\%) and (Malekifard et al., 2014) in Iran (2.80\%). And lower than that recorded in Egypt by rates of (6.5\%) by (Khalifa et al., 1988) and in Turkey (6.7\%) by (Inci, 2002). Mixed infection in the current study was detected by the rate (0.9\%) that was in agreement with other studies by (El-Fayoumy and Iman, 2006) in Egypt (1.6\%) and (Malekifard et al., 2014) in Iran (0.83\%).

According to the current study, T. equi was more prevalent than B. caballi among equines. This was in agreement with (Sigg et al., 2010; Abedi et al., 2012). A possible reason for the low prevalence of $B$. caballi could be associated with the earlier removal of the parasites after a short term of infection (Salim et al., 2008).

In the present study, the prevalence of T. equi among horses was (8.9\%) which was in agreement with (Inci, 2002) in Turkey (9\%). While, higher than (El-Fayoumy and Iman, 2006) in Egypt who recorded (7.2\%), (Malekifard et al., 2014) in Iran (6.25\%), (Sumbria et al., 2015) in India (4.17\%), and (Guven et al., 2017) in Turkey (4.8\%). And lower than that recorded in Egypt by $(21.74 \%)$ by (Radwan, 2009), (18\%) by (Ibrahim et al., 2011), (11.2\%) by (El-Kelesh et al., 2012; Turaki et al., 2014) in Nigeria (96\%) and India (11.88\%) by (Sumbria et al., 2016). Our results for $B$. caballi among horses were (2.7\%) which was in agreement with (Malekifard et al., 2014) in Iran (2.80\%). Higher than (Selim et al., 1983) that recorded B. caballi infection sporadically in Egypt and (Guven et al., 2017) in Turkey who failed to detect B. caballi among 
horses. And lower than (El-Fayoumy and Iman, 2006) in Egypt who recorded (4.8\%), (Inci, 2002) in Turkey (7.9\%). We didn't record mixed infections in horses.

In the present study, the prevalence of $T$. equi among donkeys was (7.7\%) which was in agreement with (Inci, 2002) in Turkey (7.9\%). while higher than (El-Kelesh et al., 2012) in Egypt who recorded (5.4\%), and (Abedi et al., 2015) in Iran (3.8\%). and lower than that recorded in Egypt (17.89\%) by (Radwan, 2009), in Ethiopia (12.2\%) by (Gizachew et al., 2013), and in India (35\%) by (Sumbria et al., 2016). Our result for the prevalence of B. caballi among donkeys was (5.6\%) which was in agreement with (Inci, 2002) in Turkey (5.3\%). Higher than that recorded in Egypt by (Selim et al., 1983) who recorded B. caballi infection sporadically in Egypt and Ethiopia $(1.8 \%)$ by (Gizachew et al., 2013). And lower than that recorded in Egypt (6.6\%) by (Khalifa et al., 1988). The current study showed (1.4\%) mixed infection among donkeys which was in agreement with (Khalifa et al., 1988) in Egypt who recorded (1.5\%)

Differences in prevalence among horses and donkeys either in Egypt or in other countries for T. equi and $B$. caballi may be attributed to differences in the various geographic areas in Egypt and high or low vector tick activity in the area of sampling, where climatic conditions such as temperature, humidity, and rainfall influence the habitat for ticks. Also, the time of sampling can make a difference where samples were collected at the acute or chronic stage of the disease, more aggressive treatment of infected animals, and increasing efforts of tick control (Hosseini, et al., 2016; Mahdy et al., 2016).

In the current study, there was a statistically nonsignificant relationship between the prevalence of EP and the season of the year either among horses or donkeys. This is in agreement with (Abedi et al., 2015; Malekifard et al., 2014).

Previous studies in different governorates in Egypt reported various seasonality for equine piroplasm's among horses, for the highest prevalence of $T$. equi that reported in October according to (Rashad, 1981), in January, June, and October according to (Selim et al., 1983), in summer according to (El-Fayoumy and Iman, 2006), in winter according to (Radwan, 2009) and in July according to (Salib et al., 2012). B. caballi was recorded sporadically among horses according to (Selim et al., 1983). While, among donkeys, the highest prevalence of T. equi that reported in January, June, and October according to (Selim et al., 1983), in autumn according to (Radwan, 2009). For B. caballi: it was recorded sporadically among donkeys according to (Selim et al., 1983).

Concerning the effect of sex on the prevalence of equine piroplasms among horses and donkeys, the current study showed a statistically non-significant effect of equine's sex on the incidence of $T$. equi and/or $B$. caballi among equines which mean, horses and donkeys of both sexes could be affected equally by $T$. equi and/or $B$. caballi. This is in agreement with (Abedi et al., 2015; Malekifard et al., 2014).

Concerning the effect of age on the prevalence of EP among equines either horses or donkeys, the current study showed that the highest prevalence was in the age group less than 5 years old which is statistically significant at $P$. value $(a \leq 0.05)$. Some previous studies revealed a non-significant effect of age on the prevalence of infection which means, horses and donkeys of all ages could be affected by $T$. equi and /or B. caballi according to (Abedi et al., 2015; Malekifard et al., 2014) in Iran. Others recorded the highest prevalence among different age groups such as (El-Fayoumy and Iman, 2006) in Egypt, reported that T. equi was the 
highest in 6- 10years old horses, (Radwan, 2009) in Egypt, recorded that T. equi was more prevalent among horses in less than 2 years and 2-10 years old equally, (Ibrahim et al., 2011) in Egypt, recorded that T. equi was more prevalent among horses 2-5 years old, (Turaki et al., 2014) in Nigeria reported that T. equi was the highest in more than 4 years old horses and (Salib et al., 2012) in Egypt reported that T. equi was the highest in 5-10 years old horses. For B. caballi among horses (El-Fayoumy and Iman, 2006) recorded the highest prevalence was among 1-5 years old. While among donkeys, (Radwan, 2009) recorded the highest prevalence among the age group 210 years old donkeys.

DNA amplification for the detection of equine piroplasmosis is known as a powerful tool in both the early phase of infection and in carrier animals (Rampersad et al., 2003). In the current study, molecular techniques were proved to have a higher sensitivity than microscopic examination in the detection of subclinical and carrier animals that similar to (Mahdy et al., 2016).

Concerning the prevalence of T. equi among horses in the current study, (23.4\%) was in agreement with (Ibrahim et al., 2011) in Egypt (26\%) and (Davitkov et al., 2016) in Central Balkan (22.5\%). Lower than (Alanazi et al., 2014) in Saudi Arabia (42\%) and (Mahmoud et al., 2016) in Egypt (36.4\%). And higher than (Sumbria et al., 2016). in India (14.14\%), (Hosseini et al., 2016) in Iran (11.1\%), and (Guven et al., 2017) in Turkey (8.8\%). Whereas, the molecular prevalence of B. caballi among horses in the current study, was (12.5\%), which was in agreement with (Hosseini et al., 2016) in Iran (11.1\%). Lower than (Posada-Guzmán et al., 2015) in Costa Rica (20\%) and (Mahmoud et al., 2016) in Egypt (19.3\%). And higher than (Malekifard et al., 2014) in Iran (5.83\%), (Del Pino et al., 2016) in Italy (8.9\%) and (Davitkov et al., 2016) in Central Balkan $(2.1 \%)$.

Concerning the molecular prevalence of $T$. equi among donkeys in the current study, it was (47.4\%), which was in agreement with (Mahmoud et al., 2016) in Egypt (43.1\%). While lower than (Hawkins et al., 2015) in Kenya (72\%). And higher than (Machado et al., 2011) in Brazil (31.81\%). While, the molecular prevalence of $B$. caballi among donkeys in the current study, was (21.1\%), which was in agreement with (Machado et al., 2011) in Brazil (20.45\%). While higher than (Mahmoud et al., 2016) in Egypt (15.7\%). The current study recorded dual infection among donkeys (6.6\%) which, was higher than (Machado et al., 2011) in Brazil (4.5\%).

The results of the current study were in agreement with many studies in Egypt and other countries in that PCR technique is more sensitive than microscopic examination in the diagnosis of equine piroplasms, so it is most useful in studying the epidemiological status of those parasites (Ibrahim et al., 2011; Mahmoud et al., 2016) in Egypt, (Malekifard et al., 2014; Sumbria et al., 2015) in India and (Guven et al., 2017) in Turkey.

Our results declared that T. equi is more prevalent than B. caballi, this agreed with (Abedi et al., 2014) this is due to earlier removal of $B$. caballi from blood (Qablan et al., 2013).

The results of molecular and microscopic examinations confirmed the simultaneous infection of equines in the study region with both equine piroplasms which were consistent with the finding of (Mahmoud et al., 2016).

\section{Conclusion}


In conclusion, T. equi, B. caballi are endemic among Egyptian equines. Also, PCR has higher sensitivity than microscopical examination in diagnosis of EP especially in the subclinical and chronic phases of infection. PCR techniques must be incorporated in studying EP epidemiology. There was a statistically nonsignificant relation between prevalence of infection and season and sex of equines but the highest prevalence was recorded in age group less than 5 years old.

\section{Declarations}

Author contribution: Ahmed M. Soliman conceived the study, performed field work and collection of samples and accomplished laboratory work and analyzed data. Ahmed M. Soliman wrote the draft of the manuscript. Ahmed M. Soliman, Nagwa M. Elhawary, Nashwa M. Helmy and Sahar M. Gadelhaq reviewed and revised the final draft of the manuscript. All authors read and approved the final version of the manuscript.

Conflict of interest: The authors declare that there is no conflict of interest regarding the publication of this article

Funding: No funding was received to assist with the preparation of this manuscript.

Financial and Non-financial interests: The authors have no relevant financial or non-financial interests to disclose.

All experimental conditions for animals were performed according to the guidelines approved by the Animal Care and Use Committee of Cairo University, Giza, Egypt.

\section{References}

Abedi V, Razmi GH, Seifi H (2012) Survey of piroplasmosis in horses of Turkoman breed horses by serological methods. In proceedings: The 1st national congress and festival of pure Persian horse breeds. Tehran, Iran, 188.

Abedi V, Razmi G, Seifi H, Naghibi A (2014) Seroprevalence of Babesia caballi Infection in Horses in the North Khorasan Province of Iran. Journal of Veterinary Science and Medical Diagnosis 3: 1-3.

Abedi V, Razmi G, Seifi H, Naghibi A (2015) Molecular detection of equine piroplasms in donkeys (Equus asinus) in North Khorasan province, Iran. Iranian Journal of Veterinary Research, Shiraz University 16: 202-204.

Alanazia AD, Saida AE, Morin-Adelineb V, Alyousifc MS, `Slapetab J (2014) Quantitative PCR detection of Theileria equi using laboratory workflows to detect asymptomatic persistently infected horses. Vet Parasitol 206: $138-145$.

Alhassan A, Pumidonming W, Okamura M, Hirata H, Battsetseg B, Fujisaki K, Yokoyama N, Igarashi I (2005) Development of a single-round and multiplex PCR method for the simultaneous detection of Babesia caballi and Babesia equi in horse blood. Vet Parasitol. 129: 43-49.

BrÜning A, Phipps P, Posnett E, Canning EU (1997) Monoclonal antibodies against Babesia caballi and Babesia equi and their application in serodiagnosis. Vet Parasitol. 68: 11-26.

Davitkov D, Vucicevic M, Stevanovic J, Krstic V, Slijepcevic D, Glavinic U, Stanimirovic Z (2016) Molecular detection and prevalence of Theileria equi and Babesia caballi in horses of central Balkan. Acta Parasitologica 61: $337-342$.

Del Pino LEB, Roberto N, Vincenzo V, Francesca I, Antonella C, Luca AG, Francesco B, Teresa SM (2016) Babesia caballi and Theileria equi infections in horses in Central-Southern Italy: Sero-molecular survey and associated risk factors. Ticks and Tick-borne Diseases, 1-8. 
El-Fayoumy MM, Iman MB (2006) Seroepidemiological studies on Theileria Equi (Babesia equi) and Babesia Caballi Infections Among Horses in Egypt. in $12^{\text {th }}$ Sci.Cong, Fac.Vet.Med., Assuit Univ.251-264.

El-Kelesh EAM, Radwan IG, Girgis S, Ibrahim O (2012) Serodiagnosis of equine Piroplasmosis in Egypt using CELISA. Egypt. J. Agric. Res. 90: 483-493.

Elseify MA, Helmy NM, Elhawary NM, Soliman AM (2018) Use molecular techniques as an alternative tool for diagnosis and characterization of Theileria equi. Iraqi Journal of Veterinary Sciences. 32: 1, 5-11.

Farkas R, Tánczos B, Gyurkovszky M, Földvári G, Solymosi N (2013) Serological and molecular detection of Theileria equi infection in horses in Hungary. Vet Parasitol. 192: 143-148.

Gizachew A, Schuster R K, Joseph S, Wernery R, Georgy NA, Elizabeth SK (2013) Piroplasmosis in Donkeys-A Hematological and Serological Study in Central Ethiopia. Journal of Equine Veterinary Science. 33: 18-21.

Guidi E, Pradier S, Lebert I (2015) Piroplasmosis in an endemic area: analysis of the risk factors and their implications in the control of Theileriosis and Babesiosis in horses. Parasitol Res.114: 71-83.

Guven E, Avcioglu H, Deniz A, Balkaya I, Abay U, Yavuz S, Akyüz M (2017) Prevalence and molecular characterization of Theileria equi and Babesia caballi in jereed horses in Erzurum, Turkey. Acta Parasitologica 62: 207-213.

Hawkins E, Kock R, Mckeever D, Gakuya F, Musyoki C, Chege SM, Mutinda M, Kariuki E, Davidson Z, Low B, Skilton RA, Njahira MN, Wamalwa M, Maina E (2015) Prevalence of Theileria equi and Babesia caballi as well as the identification of associated ticks in sympatric grevy's zebra (Equus Grevyi) and donkeys (Equus Africans Asinus) in Northern Kenya. Journal of Wildlife Diseases 51: 137-147.

Homer MJ, Aguilar-Delfin I, Telford SR, Krause PJ, Persing DH, (2000) Babesiosis. Clin. Microbiol. Rev. 13: $451-469$. Hosseini SR, Taktaz-Hafshejani T, Khamesipour F (2016) Molecular Detection of Theileria equi and Babesia caballi Infections in Horses by PCR Method in Iran. Kafkas Universitesi Veteriner Fakultesi Dergisi, 1-4.

Ibrahim A K, Gamil I S, Abd-El baky A A, Hussein M M, Tohamy A A (2011) Comparative Molecular and Conventional Detection Methods of Babesia equi (B. Equi) in Egyptian Equine. Global Veterinaria 7: 201-210.

Inci A (2002) Prevalence of Babesia equi (Laveran, 1901) and Babesia caballi (Nuttall, 1910) in equids in the Kayseri region on the basis of microscopic examination of blood smears. Saglk Bilimleri Dergisi, Firat Universitesi.

Veteriner.16: 85-88.

Khalifa R, Monib M E M, Mandour AM (1988) A study on the parasites infecting equines in Assiut governorate. Assuit Vet. Med. J. 20: 67-76.

Kim C, Beatriz L, Blanco C, Alhassan A, Iseki H, Yokoyama N, Xuan X, Igarashi I (2008) Diagnostic real-time PCR assay for the quantitative detection of Theileria equi from equine blood samples. Vet Parasitol. 151: 158-163.

Levine ND (1982) Veterinary Protozoology. lowa State Univerity Press.Ames.

Machado R Z, Toledo CZP, Teixeira MC, André MR, Freschi CR, Sampaio PH (2012) Molecular and serological detection of Theileria equi and Babesia caballi in donkeys (Equus asinus) in Brazil. Veterinary Parasitology 186: 
461-465.

Mahdy OA, Nassar AM, Mohamed B S, Mahmoud MS (2016) Comparative Diagnosis Utilizing Molecular and Serological Techniques of Theileria equi Infection in Distinct Equine Populations in Egypt. International Journal of Chem Tech Research 9: 185-197.

Mahmoud M S, El-ezz NTA, Abdel-shafy S, Nassar SA, Namaky AH, El-Khalil WKB, Knowles D Kappmeyer L, Silva MG, Suarez CE (2016) Assessment of Theileria equi and Babesia caballi infections in equine populations in Egypt by molecular, serological, and hematological approaches. Parasites and Vectors 9: 1-10.

Malekifard F, Tavassoli M, Yakhchali M, Darvishzadeh R (2014) Detection of Theileria equi and Babesia caballi using microscopic and molecular methods in horses in suburb of Urmia, Iran. Vet. Res. Forum 5: 129-133.

Mehlhorn H, Schein E (1998) Redescription of Babesia equi Laveran, 1901 as Theileria equi Mehlhorn, Schein 1998. Parasitol. Res. 84: 467-475.

Posada-Guzmán MF, Dolz G, Romero-Zúñiga JJ, Jiménez-Rocha AE (2015) Detection of Babesia caballi and Theileria equi in Blood from Equines from Four Indigenous Communities in Costa Rica. Veterinary Medicine International 1-7.

Qablan MA, Oborník M, Petrzelková KJ, Sloboda M, Shudiefat MF, Horin P, Lukes J, Modrý D (2013) Infections by Babesia caballi and Theileria equi in Jordanian equids: epidemiology and genetic diversity. Parasitology 140: 10961103.

Quintão-Silva MG, Ribeiro MFB (2003) Infection Rate of Babesia spp. Sporokinetes in Engorged Boophilus microplus from an Area of Enzootic Stability in the State of Minas Gerais, Brazil. Mem Inst Oswaldo Cruz. 98: 999-1002.

Radwan AMM (2009) An Investigation on Parasitic Infection in Equines., Banha University, Faculty of Veterinary Medicine, Department of Parasitology, Thesis (M.V.sc.).

Rampersad J, Cesar E, Campbell MD, Samlal M, Ammons D (2003) A field PCR for the routine detection of Babesia equi in horses. J. Vet. Parasitol. 114: 81- 87.

Rashad SM (1981) The incidence of Babesia equi in horses and donkeys by the use of haemagglutination test. Cairo University, Faculty of Veterinary Medicine, Parasitology Department. Thesis (M.V.SC.).

Rothschild CM (2013) Equine Piroplasmosis. Journal of Equine Veterinary Science 33: 497-508.

Rüegg SR, Torgerson P, Deplazes P (2007) Mathis a. Age-dependent dynamics of Theileria equi and Babesia caballi infections in southwest Mongolia based on IFAT and/or PCR prevalence data from domestic horses and ticks. Parasitology. 134: 939-947.

Salib FA, Youssef RR, Rizk LG, Said SF (2012) Epidemiology, diagnosis, and therapy of Theileria equi infection in Giza, Egypt. Veterinary World 6: 76-82.

Salim B O M, Hassan S M, Bakheit M A, Alhassan A, Igarashi I, Karanis P, Abdelrahman MB (2008) Diagnosis of Babesia caballi and Theileria equi infections in horses in Sudan using ELISA and PCR. Parasitol. Res.103: 11451150.

Scoles GA, Ueti MW (2015) Vector ecology of equine piroplasmosis. Annu. Rev. Entomol. 60: 561-580. 
Selim MK, Abdel-Gawwad AMH (1982) Observation on B. equi in latently infected donkeys after splenectomy. Vet. Med. J. Fac. Med. Cairo. Univ.

Selim, MK, EL-Mawla BG, El-seify MA, Abdel-Halim F, Rashad S M, Ahmed ZG (1983) On the incidence and epidemiology of equine babesiosis in relation to its tick vectors in Egypt. Journal of the Egyptian Veterinary Medical Association 43: 213-220.

Sigg L, Gerber V, Gottstein B, Doherr M G, Frey C F, (2010) Seroprevalence of Babesia caballi and Theileria equi in the Swiss horse population. Parasitology International 59: 313-317.

Sumbria D, Singla L, Amrita S, Kaur P (2015) Detection of Theileria species infecting equine population in Punjab by 18S rRNA PCR. Indian Journal of Animal Research, 0-6.

Sumbria D, Singla L D, Sharma A (2016) Theileria equi and Babesia caballi infection of equids in Punjab, India: a serological and molecular survey. Trop Anim Health Prod. 48: 45-52.

Turaki UA, Kumsha HA, Biu AA, Bokko PB (2014) Prevalence of Piroplasmosis amongst local horses in Northeastern Nigeria. IOSR Journal of Agriculture and Veterinary Science 7: 4-7.

Zobba R, Ardu M, Niccolini S, Chessa B, Manna L, Cocco R, Luisa M, Parpaglia P (2008) Clinical and Laboratory Findings in Equine Piroplasmosis. Journal of Equine Veterinary Science 28: 301-308.

Zweygarth E, Lopez-Rebollar LM, Nurton J, Guthrie AJ (2002) Culture, isolation, and propagation of Babesia caballi from naturally infected horses. Parasitol Res. 88: 460-472.

\section{Figures}

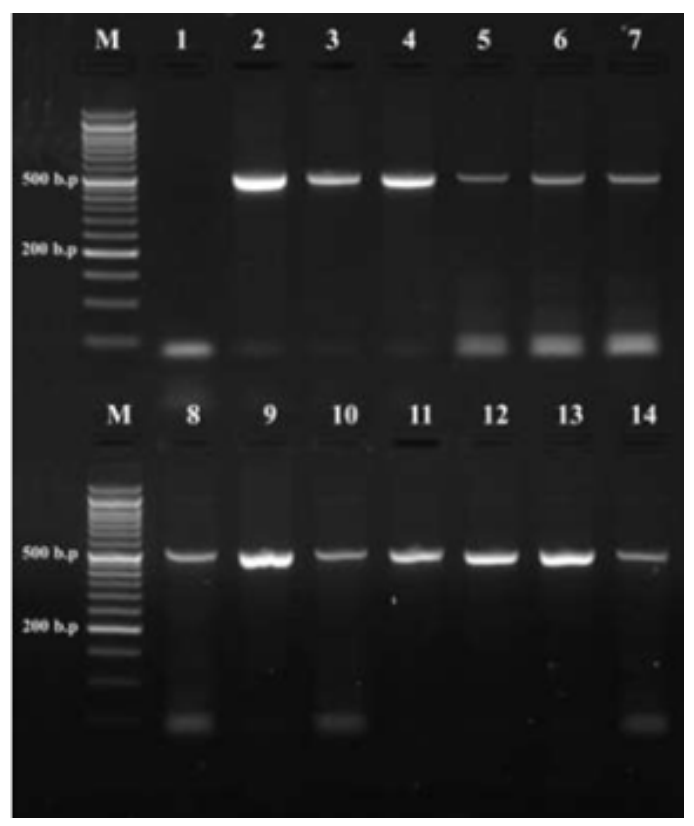

\section{Figure 1}

Detection of B. caballi by Conventional PCR at 540 bp fractionated on 1.5\% agarose gel. Lane M: 50 bp DNA ladder, Lane 1: B. caballi negative control, Lane 2: B. caballi positive control, Lane 3-14 B. caballi positive field samples. 


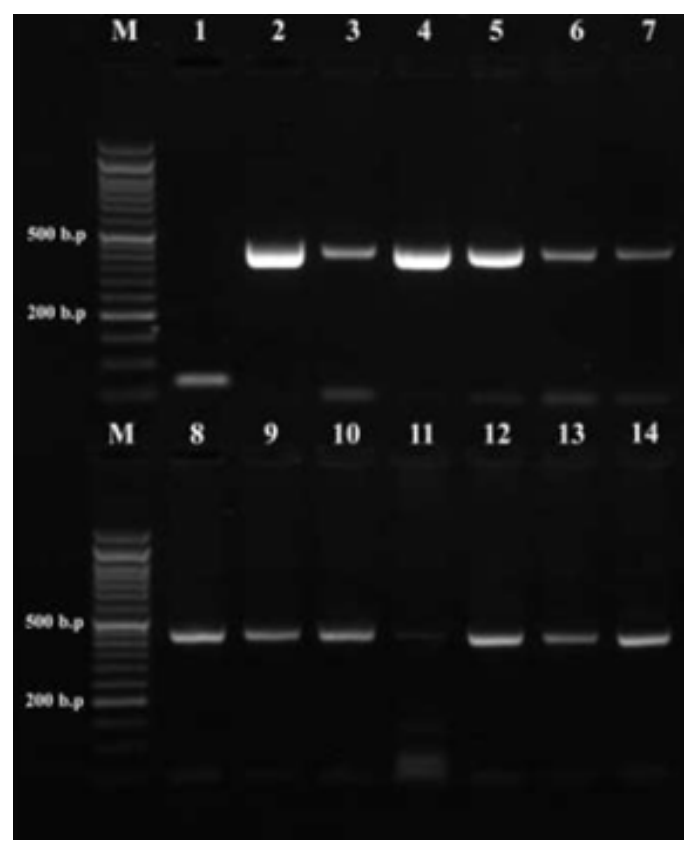

\section{Figure 2}

Detection of T. equi by Conventional PCR at 392 bp fractionated on 1.5\% agarose gel. Lane M: 50 bp DNA ladder, Lane 1: T. equi negative control, Lane 2: T. equi positive control, Lane 3-14 T. equi positive field samples 